\title{
Simulation of Runoff and Suspended Sediment Transport Rate in a Basin with Multiple Watersheds
}

\author{
Ching-Nuo Chen • Chih-Heng Tsai · Chang-Tai Tsai
}

Received: 27 November 2009 / Accepted: 27 October 2010 /

Published online: 19 November 2010

(C) The Author(s) 2010. This article is published with open access at Springerlink.com

\begin{abstract}
Accurate runoff and suspended sediment transport rate models are critical for watershed management. In this study, a physiographic soil erosion-deposition (PSED) model is used in conjunction with GIS, to simulate the runoff and sediment transport process during storm events in a multi-watershed basin. This PSED model is verified using three typhoon events and 33 storm events in Cho-Shui River Basin, located in central Taiwan. Cho-Shui River Basin has 11 sub-watersheds displaying a variety of hydrologic and physiographic conditions as well as high concentrations of suspended sediment in river flow and a steep average channel bed slope of $2 \%$. The results show the capability, applicability, and accuracy of the PSED model for multi-watershed basins.
\end{abstract}

Keywords Multi-watershed river basin • Physiographic soil erosion-deposition model (PSED) • Discharge hydrograph • Suspended sediment transport rate • GIS

\section{Introduction}

Surface runoff is created when the precipitation rate is larger than the infiltration rate of a soil. High velocity runoff results in both soil erosion and the transportation

C.-N. Chen $(\bowtie) \cdot$ C.-T. Tsai

Department of Hydraulics and Ocean Engineering, National Cheng-Kung University, No. 1, University Road, Tainan City 70101, Taiwan, China e-mail: cnchen@mail.hyd.ncku.edu.tw

C.-N. Chen

Sustainable Environment Research Center, National Cheng-Kung University, No. 1, University Road, Tainan City 70101, Taiwan, China

C.-H. Tsai

Department of Leisure Resources and Green Industries, Leader University, No. 188, Section 5, Anjhong Road, Tainan City 70970, Taiwan, China 
of the eroded soil into downstream rivers. Runoff and erosion are two critical factors for designing hydraulic infrastructures such as reservoirs and weirs. Thus, accurate estimation of runoff and sediment transport is essential when developing numerical models of open channels, water quality, sediment erosion and deposition.

Although many rainfall-runoff models exist that can estimate runoff using the rainfall data of a watershed, none can simulate sediment transport. On the other hand, the prevalent empirical approaches used to simulate soil erosion, such as Universal Soil Loss equation (USLE) (Wischmeier et al. 1958) and Revised Universal Soil Loss equation (RUSLE; Renard et al. 1991), cannot simulate the runoff and the sediment transport of a watershed. Because sediment transport is related to surface runoff and both interact with physiographic conditions, they should be considered simultaneously in a simulation model. Many physically based models have been developed to address this problem, such as ANSWERS (Beasley et al. 1980), CREAMS (Knisel 1980), GUESS (Rose et al. 1983), EPIC (Williams et al. 1984), WEPP (Nearing et al. 1989), AGNPS (Young et al. 1989), GUEST (Misra and Rose 1990), and EUROSEM (Morgan et al. 1998). These models, based on the conservation of mass and energy, result in partial differential equations used to simulate runoff and sediment transport for independent rainfall events. However, these models still use empirical approaches to estimate soil erosion during the event. For example, EPIC and WEPP apply USLE to simulate soil erosion.

Dealing with hydrologic and physiographic parameters can be tedious when implementing physically based models. For example, WEPP requires 50 parameter inputs (Brazier et al. 2000) such as plant species, fractional vegetation cover, initial saturation level, organic matter, interrill erodibility, effective hydraulic conductivity, cation exchange capacity, etc. To handle large hydrologic and physiographic datasets, GIS can be utilized. For example, some studies linked GIS with USLE (Bhattarai and Dutta 2007; Mishra and Deng 2009; Chou 2010; Jain and Das 2010) or modified form of USLE (Wang et al. 2009). Recently, many studies have used GIS to combine rainfall-runoff models with sediment transport models and soil erosion models to simulate runoff and sediment transport within a watershed (Murakami et al. 2001; Wongsa et al. 2002; Sun et al. 2002; Paringit and Nadaoka 2003; Chen et al. 2004, 2006; Jain et al. 2005; Yuan et al. 2007). Despite using GIS, these models continue to simplify the hydrologic and physiographic parameters. These simplifications result in limitations associated with model applicability and accuracy. Consequently, these models can only obtain accurate results for small watersheds with simple hydrologic and physiographic conditions, and are inadequate for large river basins with multiple watersheds containing complex rainfall patterns, soil types and land uses.

In this study, a physiographic Soil Erosion-Deposition Model (PSED) model is developed to simulate rainfall-runoff and sediment transport processes during storm events in a multi-watershed basin. The watershed contains 11 sub-watersheds which display a variety of hydrologic and physiographic conditions. The erosion-deposition model considers suspended sediment transport, bed load transportation, entrained sediment, and deposited sediment in the continuity equations. Accordingly, no simplification of physiographic parameters except homogenization of the landscape in each computational cell is made using the proposed PSED model. Therefore, the proposed model can provide accurate simulation results of runoff, suspended sediment transport, and sediment yield of a multi-watershed river basin.

The study area is Cho-Shui River Basin, the longest river which is located in the central western region of Taiwan with a basin area of $3,155 \mathrm{~km}^{2}$. This PSED model 
is verified using three typhoon events, Typhoon Herb (1996), Typhoon Zeb (1998), and Typhoon Nari (2001), and 33 storm events in 1998. Observed runoff hydrographs and suspended sediment transport rates are compared with that of the model outputs to verify the proposed PSED model.

\section{Physiographic Soil Erosion-Deposition (PSED) Model}

The PSED model combines an overland runoff model and a soil erosion-deposition model. The details of these two models are described as follows.

\subsection{Overland Runoff Model}

The overland runoff model determines the transportation of the overland flow in the watershed. The continuity equation can be expressed as (Chen et al. 2006):

$$
A_{i} \frac{\partial h_{i}}{\partial t}=\sum_{k} Q_{i, k}\left(h_{i}, h_{k}\right)+P_{e i}(t)
$$

where $t$ is time; $A_{i}$ is the area of the cell $i ; h_{i}$ and $h_{k}$ are surface water elevation of cell $i$ and $k$, respectively; $O_{i, k}$ is the discharge flowing into cell $i$ from the adjacent cell $k$; $P_{e i}$ is the effective rainfall volume per second or effective rainfall intensity multiplied by the area of cell $i$. The effective rainfall volume can be obtained using the following equation (Chow et al. 1988):

$$
\begin{aligned}
& P^{\prime}=\frac{(P-0.2 S)^{2}}{(P+0.8 S)} \\
& S=\frac{25400}{C N}-254
\end{aligned}
$$

where $P$ is the depth of the total precipitation $(\mathrm{mm}) ; P^{\prime}$ is the depth of excess precipitation or direct runoff $(\mathrm{mm}) ; S$ is less than or equal to the potential maximum retention $(\mathrm{mm}) ; C N$ is curve number which depends on soil type and land use.

If no flow barrier exists, the flow between adjacent cells can be calculated using the Manning equation. The following equations are used to calculate the flow, $Q_{i, k}$, from cell $k$ to cell $i$.

$$
\begin{gathered}
Q_{i, k}=\frac{h_{k}-h_{i}}{\left|h_{k}-h_{i}\right|} \cdot \Phi \cdot \sqrt{\left|h_{k}-h_{i}\right|} \quad \text { for } \quad \frac{\partial Q_{i, k}}{\partial h_{i}} \leq 0 \\
Q_{i, k}=\Phi \cdot \sqrt{\left|h_{k}-h_{i}\right|} \quad \text { for } \quad \frac{\partial Q_{i, k}}{\partial h_{i}}>0
\end{gathered}
$$

where $\bar{h}_{i, k}$ is the elevation of water table at the boundary of cell $i$ and $k$; and the flow parameter $\Phi=A_{w} R^{2 / 3} /(n \sqrt{\Delta x}), \Delta x$ is the distance between centroid of cell $i$ and $k ; n$ is Manning's roughness coefficient; $A_{w}$ is the cross-section area of the boundary between two cells; and $R$ is the hydraulic radius at the boundary. 
Flow barriers, such as roads, embankments, field ridges, and banks, are treated as broad crested weirs. Two conditions may exist: free overfall weir and submerged weir. The following equations describe each condition $\left(h_{k}>h_{i}\right)$.

(A) Free overfall weir $\left(h_{i}-h_{w}\right)<\frac{2}{3}\left(h_{k}-h_{w}\right)$ :

$$
Q_{i, k}=\mu_{1} b \sqrt{2 g}\left(h_{k}-h_{w}\right)^{3 / 2}
$$

(B) Submerged weir $\left(h_{i}-h_{w}\right) \geq \frac{2}{3}\left(h_{k}-h_{w}\right)$ :

$$
Q_{i, k}=\mu_{2} b \sqrt{2 g}\left(h_{i}-h_{w}\right)\left(h_{k}-h_{i}\right)^{1 / 2}
$$

where $h_{w}$ is the elevation of weir crest, that is the elevation of road, bank top, or ground; $b$ is the effective width of the weir, or the length of the border between two adjacent cells; $g$ is acceleration due to gravity; $\mu_{1}$ and $\mu_{2}$ are weir discharge coefficients for free overfall weir and submerged weir, respectively. Tsai and Tsai (1997) suggested $\mu_{1}=0.36 \sim 0.57$ and $\mu_{2}=2.6 \mu_{1}$. In this study, we use $\mu_{1}=0.46$ and $\mu_{2}=1.20$.

Applying a finite difference scheme, Eq. 1 can be expressed as:

$$
h_{i}^{m+1}=h_{i}^{m}+\frac{\left(\sum_{k} Q_{i, k}^{m}+P_{e i}^{m}\right)}{A_{i}} \cdot \Delta t
$$

where the superscript, $m$, represents the time index, $t_{m}$, for the variables, $Q, P$, and $h$; $\Delta t$ is time increment between $t_{m}$ and $t_{m+1}$. The relationship between flow, $Q_{i, k}$, and water table elevations, $h_{i}$ and $h_{k}$, for two adjacent cells is expressed by either Eqs. 4 and 5 or 6 and 7. The water depth of cell $i, D_{i}$, can be obtained by $D_{i}=h_{i}-z_{i}, z_{i}$ is the bed elevation of cell $i$. With the equations listed thus far and any physiographic and hydrologic data, the water table hydrograph of each cell can be obtained.

\subsection{Soil Erosion-Deposition Model}

To simulate the erosion and deposition processes in the study area, sediment transport rate and bed load sediment variation are obtained from the bed load transport rate formula, continuity equations of suspended sediment and bed load (Chen et al. 2006).

$$
\begin{gathered}
\frac{\partial V_{s i}}{\partial t}=\sum_{k} Q_{S C_{i, k}}+Q_{s e i}-Q_{s d i}+R_{D T i} \\
(1-\lambda) \frac{\partial V_{d i}}{\partial t}=\sum_{k} Q_{S B_{i, k}}-Q_{s e i}+Q_{s d i}-R_{D T i}
\end{gathered}
$$

where $V_{s i}$ is the volume of suspended sediment in cell $i\left(V_{s i}=A_{i} \times D_{i} \times C_{i}\right)$; $C$ is the volumetric concentration of suspended sediment; $\lambda$ is porosity; $V_{d i}$ is the volume of the predetachment erosion layer in cell $i ; Q_{S C_{i, k}}$ and $Q_{S B_{i, k}}$ are transport rates of suspended sediment and bed load, respectively, from cell $k$ to adjacent cell $i ; R_{D T i}$ is 
the rainfall detachment rate of cell $i ; Q_{s e i}$ is the entrained rate of cell $i$; and $Q_{s d i}$ is the deposition rate of cell $i$.

\section{(1) Rainfall detachment rate}

Erosion resulting from rainfall detachment is based on soil type, vegetation, and water depth. When the water depth exceeds a depth of three times the diameter of a raindrop, raindrops are considered to have no direct impact on the soil surface and the rainfall detachment rate is considered zero (Mutchler and Young 1975). Raindrop diameter is correlated with the rainfall intensity and is calculated by Ma's formula as follows (Ma 1995).

$$
d_{50}=1.560 I^{0.096}
$$

where $d_{50}$ is the median diameter of raindrops $(\mathrm{mm})$; and $I$ is rainfall intensity $(\mathrm{mm} / \mathrm{hr})$.

When the flow depth is less than three times the diameter of raindrop, the rainfall detachment rate is calculated as follows,

$$
R_{D T i}=\alpha \cdot I^{\beta} \cdot A_{i}
$$

where $\alpha$ and $\beta$ are yet to be determined. Hu et al. (1995) suggested that the value of $\alpha$ should be between 18.36 and 21.72 and $\beta$ be between 0.81 and 1.29 . In this study, $\alpha=20$ and $\beta=1.0$.

\section{(2) Entrained and deposition sediment}

Itakura and Kishi (1980) suggested that the sediment entrainment rate $\left(q_{s e}\right)$ of the channel bed can be expressed as:

$$
q_{s e}=0.008 \sqrt{s g d}\left[0.14 \frac{\rho}{\rho_{s}}\left(14 \sqrt{\tau_{*}}-\frac{0.9}{\sqrt{\tau_{*}}}\right)-\frac{\omega_{s}}{\sqrt{s g d}}\right]
$$

Where $s=\left(\rho_{s}-\rho\right) / \rho$ is the submerged specific gravity of the sediment; $\rho_{s}$ and $\rho$ are density of the sediment and the clear water, respectively; $d$ is the diameter of sediment; $\omega_{s}$ is the fall velocity of sediment; $\tau_{*}$ is dimensionless bed shear stress $\left(=u_{*}^{2} / s g d\right)$; and $u_{*}$ is the shear velocity. The deposition rate of sediment, $q_{s d}$, is expressed as follows,

$$
q_{s d}=\omega_{s} C_{a}
$$

where $C_{a}$ is the volumetric concentration of suspended sediment near the channel bed. $C_{a}$ can be approximated by the suspended sediment concentration at the $5 \%$ depth from the channel bed (Shimizu et al. 1990). The entrained sediment rate and deposition rate can be expressed as:

$$
\begin{gathered}
Q_{s e i}=q_{s e} \cdot A_{i} \cdot c^{\prime} \quad(\text { if cell } i \text { is a land cell }) \\
Q_{s e i}=q_{s e} \cdot A_{i} \quad(\text { if cell } i \text { is a river cell }) \\
Q_{s d i}=q_{s d} \cdot A_{i}
\end{gathered}
$$

where $c^{\prime}$ is the crop management factor based on land use type (Chen et al. 2004). 


\section{(3) Bed load transport rate}

Sediment transport occurs when the shear stress exerted on the bed material exceeds the critical shear stress. In this study, the equation to calculate the bed load transport rate is as follows (Chen et al. 2006):

$$
\gamma D S_{f}=0.047\left(\gamma_{s}-\gamma\right) d+0.25\left(\frac{\gamma}{g}\right)^{1 / 3}\left(\frac{\gamma_{s}-\gamma}{\gamma_{s}}\right)^{2 / 3} q_{b}^{2 / 3}
$$

where $S_{f}$ is the friction slope; $\gamma_{s}$ and $\gamma$ are specific weight of sediment and clear water, respectively; $q_{b}$ is the bed load transport rate per unit bed width.

Additionally, the bed load discharge between two adjacent cells can be expressed as follows.

$$
\begin{gathered}
Q_{S B_{i, k}}=q_{b_{i, k}} \cdot b \cdot c^{\prime} \text { (if cell } i \text { is a land cell) } \\
Q_{S B_{i, k}}=q_{b_{i, k}} \cdot b \text { (if cell } i \text { is a river cell) }
\end{gathered}
$$

(4) Volumetric concentration of suspended sediment and bed variation

Applying a finite difference scheme, Eq. 9 can be approximated as follows.

$$
C_{i}^{m+1}=\frac{\left(\sum_{k} Q_{S C_{i, k}}^{m}+Q_{s e i}^{m}-Q_{s d i}^{m}+R_{D T i}^{m}\right)}{A_{i} D_{i}^{m+1}} \cdot \Delta t
$$

where, $Q_{S C_{i, k}}$ is the discharge of suspended sediment between two adjacent cells and can be determined by the flow direction of $Q_{i, k}$. If water flows from cell $k$ to cell $i, Q_{S C_{i, k}}=\left|Q_{i, k}\right| \times C_{k}$. If water flows from cell $i$ to cell $k, Q_{S C_{i, k}}=-\left|Q_{i, k}\right| \times C_{i}$. In addition, $Q_{s e i}, Q_{s d i}, R_{D T i}$, and $D_{i}$ can be obtained from Eqs. 15a, 15b, 16, 12, and 9, respectively.

Similarly, Eq. 10 can be approximated using finite difference as follows:

$$
\begin{gathered}
\Delta z_{i}=\frac{\left(\sum_{k} Q_{S B_{i, k}}^{m}+Q_{s e i}^{m}-Q_{s d i}^{m}-R_{D T i}^{m}\right)}{A_{i}(1-\lambda)} \cdot \Delta t \\
z_{i}^{m+1}=z_{i}^{m}+\Delta z_{i}
\end{gathered}
$$

where, $\Delta z_{i}$ is the change in bed elevation (a positive value represents deposition and a negative value represents erosion). The bed load discharge, $Q_{S B_{i, k}}$, between two adjacent cells is determined by the direction of $Q_{i, k}$. If the bed load is flowing into cell $i$, the value of $Q_{S B_{i, k}}$ is positive and can be obtained using Eq. 18a and 18b; the value is negative if water flows out of cell $i$.

\section{Study Area: Chou-Shui River Basin, Taiwan}

Chou-Shui River Basin is located in the central western region of Taiwan with a basin area of $3,155 \mathrm{~km}^{2}$. At $186 \mathrm{~km}$ in length, the Chou-Shui River is the longest river in Taiwan. Due to significant erosion resulting from the soil type liable to erode and steep slope of the main river channel, Chou-Shui River is also known 


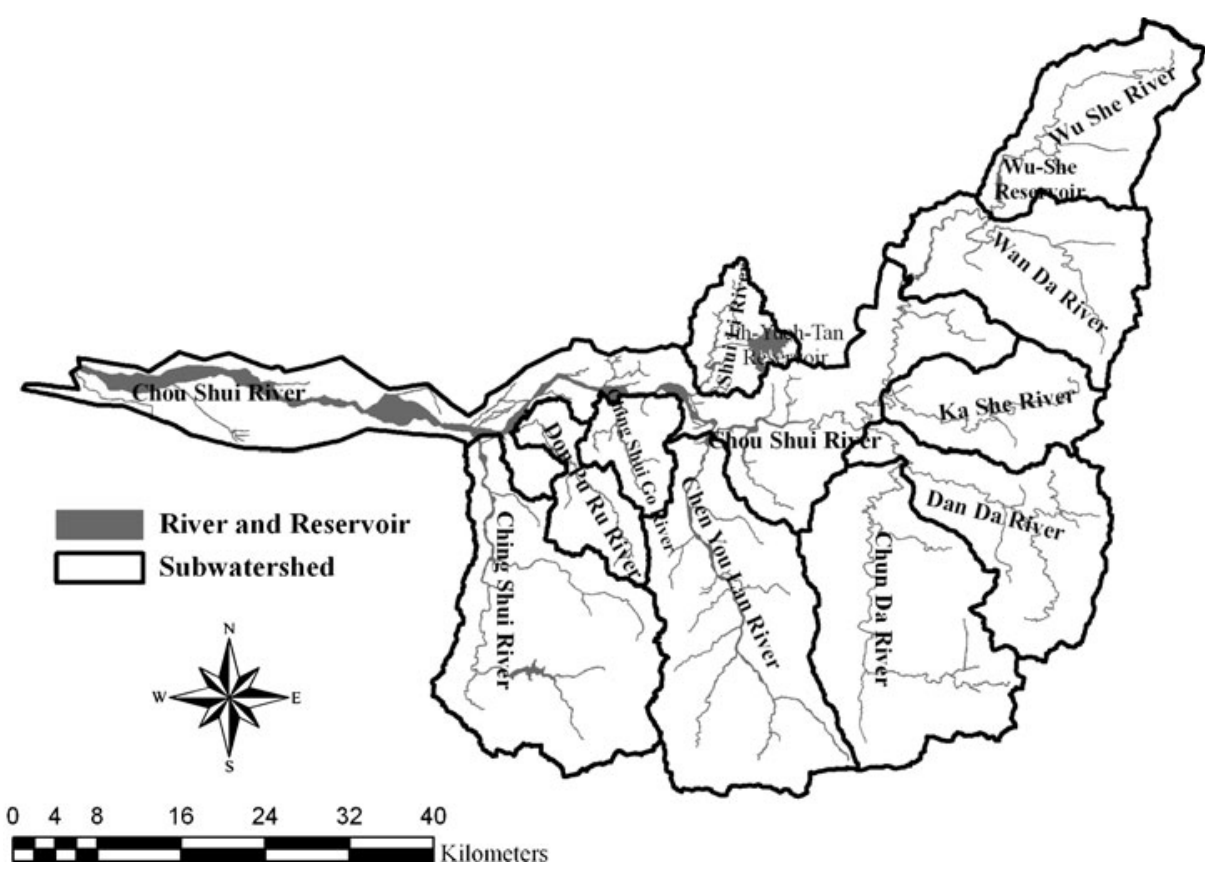

Fig. 1 Chou-Shui River Basin with 11 subwatersheds

for high turbidity levels. The elevation of its source is $3,200 \mathrm{~m}$ above sea level (a.s.l.) and the average channel bed slope is $1.72 \%$. Before the river flows west into the Taiwan Strait, it collects water from 11 sub-watersheds: Wushe, Wanda, Kashe, Danda, Chunda, Chenyoulan, Chingshui, Donpuru, Chingshuigo, Shuili, and ChouShui River mainstream watersheds (Fig. 1).

\section{Application of GIS}

Due to the variation in topography, landform, vegetation, and land use in the basin, the runoff process caused by rainfall and the induced erosion may be different spatially. Therefore GIS is used to discretize the study area into sub-watersheds and computational cells based on topography, landform, vegetation and landuse. GIS is also used to calculate and analyze the hydrologic and physiographic factors of each cell.

Each sub-watershed is defined based on the digital elevation model (DEM) provided by the Center for Space and Remote Sensing Research at the National Central University, in Taiwan (Fig. 2). The ground resolution is $40 \mathrm{~m} \times 40 \mathrm{~m}$. Based on the DEM, flow direction analysis, and accumulated discharge analysis (Chen et al. 2004), the main river channels and ridges between any two sub-watersheds can be determined and then Chou-Shui River Basin is divided into 11 sub-watersheds. Each sub-watershed consists of two clusters of cells. One represents the river cells, and the other represents the land cells. 


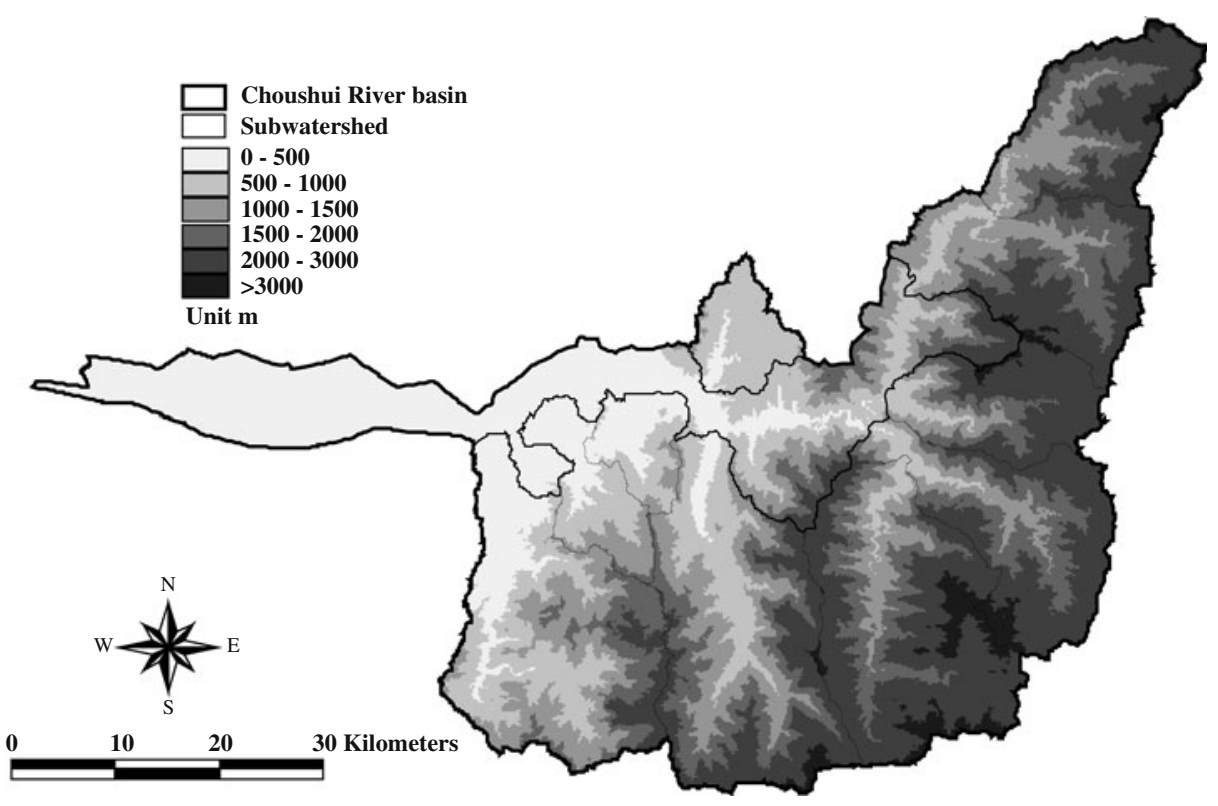

Fig. 2 Digital elevation model (DEM) of Chou-Shui River Basin

Hence, $\operatorname{ArcGIS}^{\mathrm{TM}}\left(\mathrm{ArcView}^{\circledR}\right.$ and Arc/Info $\left.{ }^{\circledR}\right)$ is used, along with some extension modules (spatial analysis, hydrologicmodel, 3D Analyst, Network Analyst) and the

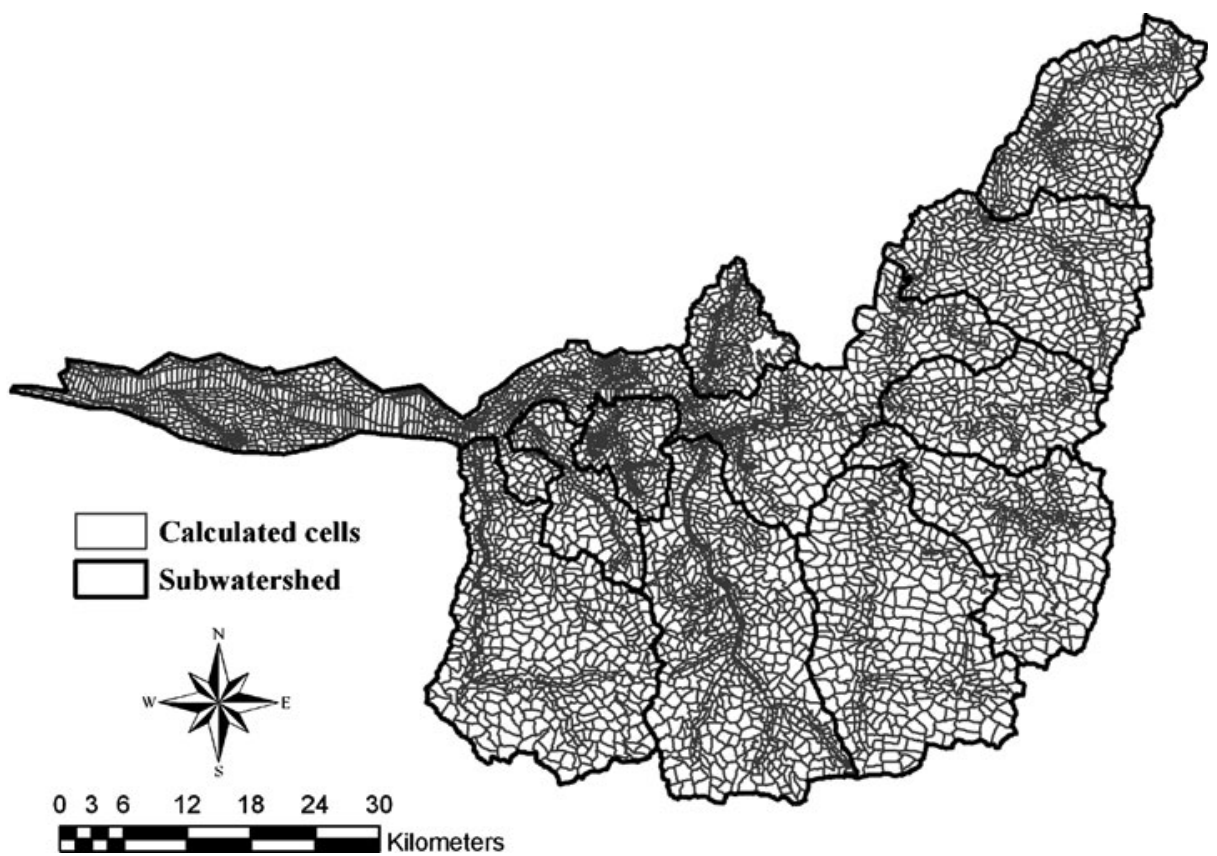

Fig. 3 Computational cells of Chou-Shui River Basin 
Object-Oriented Programming Language (Avenue), to handle the large hydrologic and physiographic datasets. The data consists of slope, area, average elevation, centroid coordinate, precipitation, $\mu_{1}, \mu_{2}, b, c^{\prime}, d, n, C N, \alpha, \beta, \lambda$.

After defining the main river channels, the width of river cells are assigned based on the measured cross-sections in the field. In addition, land cells are assigned according to soil type, land use, and road system. Subsequently, small, long and narrow cells were integrated into one cell and large cells were further discretized into multiple cells with the appropriate sizes such that enough information is contained for the simulation model. As a result, there are 6,421 cells of Chou-Shui River Basin with 11 sub-watersheds (Fig. 3). The average size of each computational cell is about $0.49 \mathrm{~km}^{2}$.

\section{Hydrologic and Physiographic Data}

Hydrologic data are used as input for the simulation model as well as for model verification. There are 34 rain gauges and 10 river gauging stations in the study area (Fig. 4). Since the rain gauges are not uniformly distributed, we apply the Thiessen polygon method (Tseng and Chou 2000) to determine the control area of each rain gauge (Fig. 5).

Coupling the DEM (Fig. 2) with the cell map (Fig. 3), the geometric properties of each cell, such as slope, area, average elevation, etc., were obtained. In addition, GIS was used to handle physiographic data such as land use and vegetation which

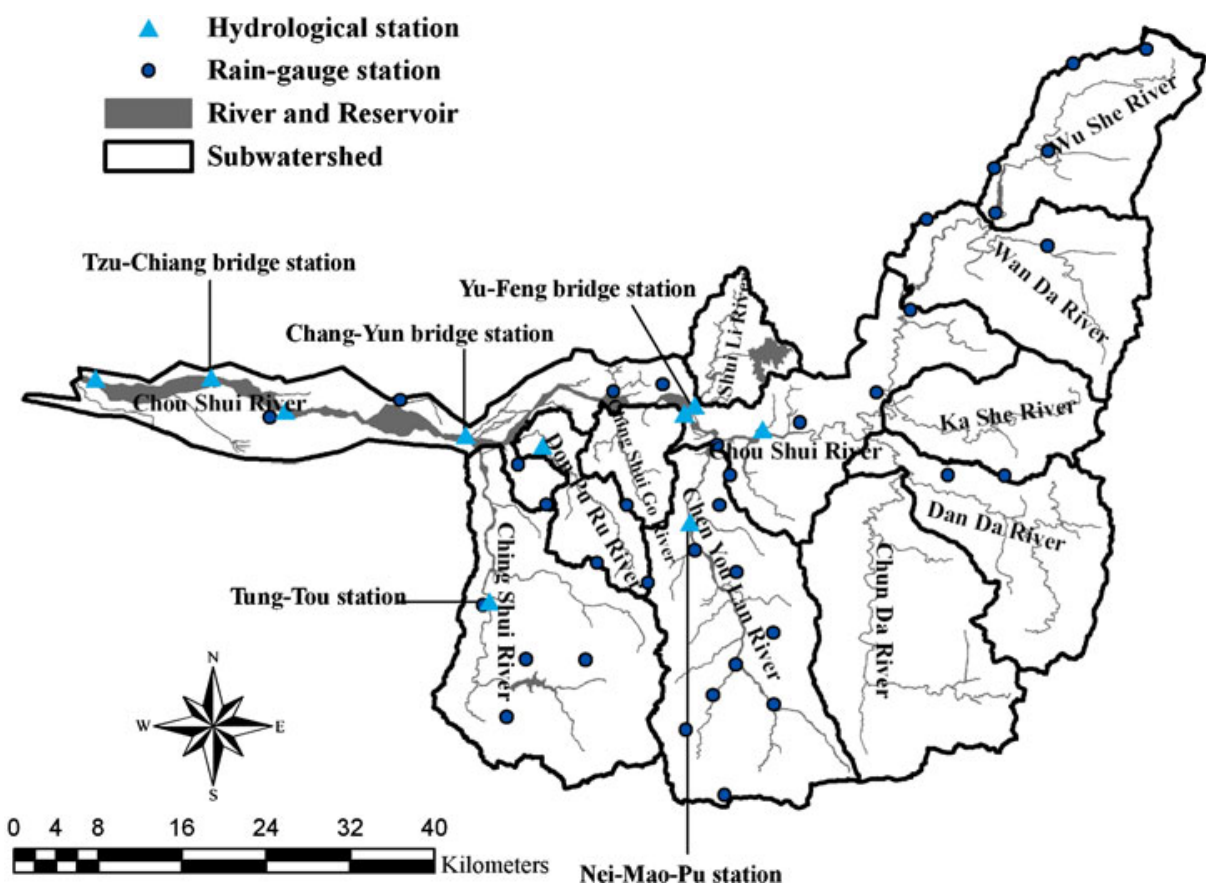

Fig. 4 Locations of rain gauges and river gauging stations in the Chou-Shui River Basin 


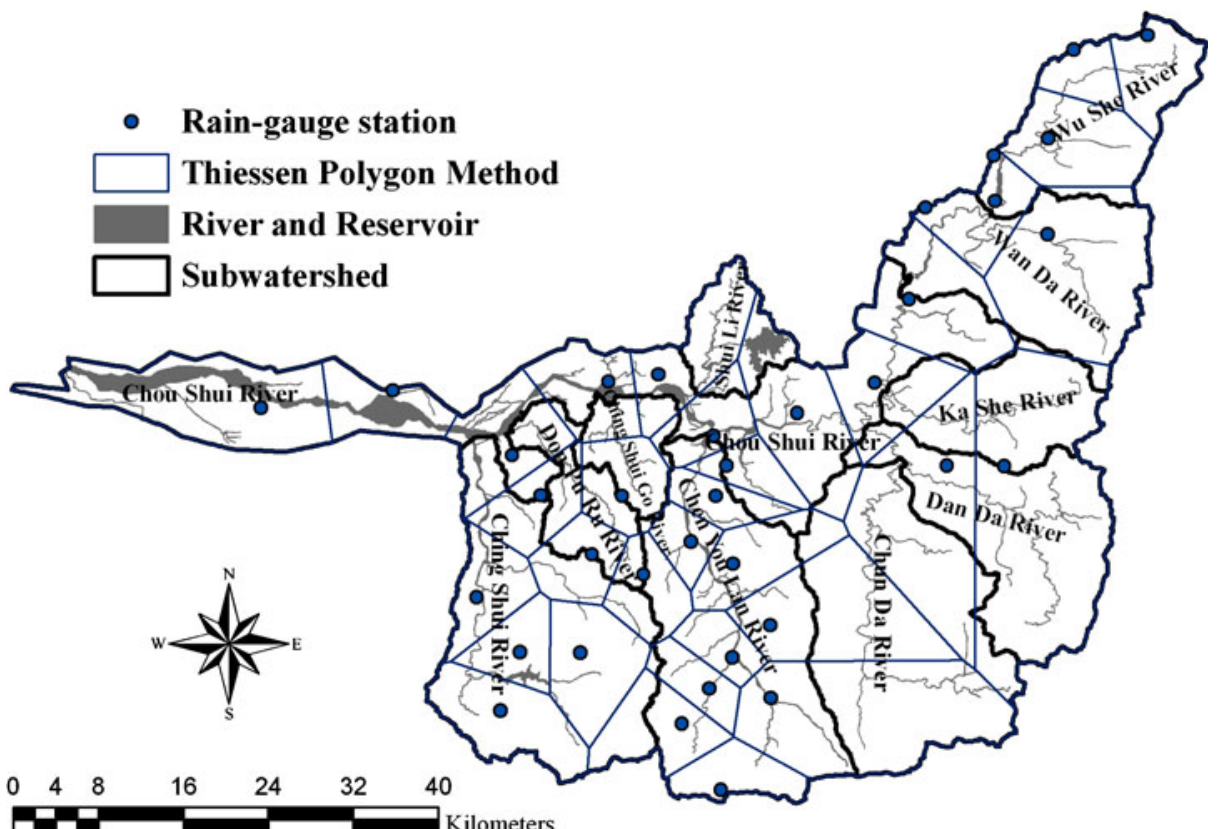

Fig. 5 Rain gauge control areas (obtained by Thiessen polygon method)

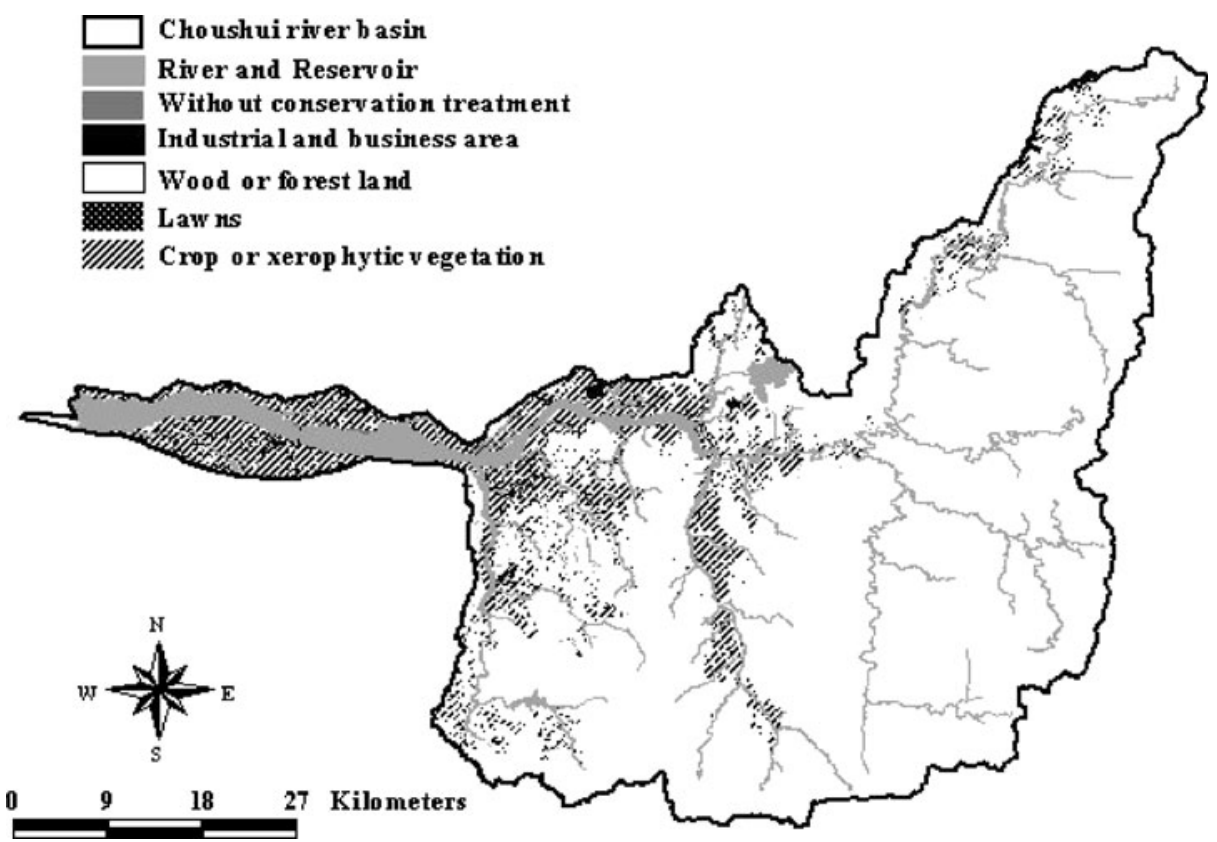

Fig. 6 Land use distribution of the Chou-Shui River Basin 
Table 1 Manning's roughness coefficients for various land uses (Chen et al. 2004)

\begin{tabular}{lll}
\hline Land uses & $\begin{array}{l}\text { Manning's } \\
\text { roughness }\end{array}$ & $\begin{array}{l}\text { Crop management } \\
\text { factor } c^{\prime}\end{array}$ \\
\hline Meadow & 0.35 & 0.15 \\
Lawns & 0.25 & 0.05 \\
Without conservation treatment & 0.2 & 1.00 \\
River and reservoir & 0.035 & 0.00 \\
Paddy field & 0.10 & 0.10 \\
Crop or xerophytic vegetation & 0.35 & 0.25 \\
Orchard & 0.40 & 0.20 \\
Wood or forest land & 0.45 & 0.01 \\
Bush & 0.35 & 0.01 \\
Industrial and business area & 0.10 & 0.01 \\
\hline
\end{tabular}

affect the value of Manning's roughness coefficient in the overland runoff model as well as the bed load transport rate and suspended transport rate in the Soil erosion-deposition model. Coupling the land use map (Fig. 6) with the cell map, the physiographic properties of land use and vegetation of each cell were obtained. Based on these physiographic properties, Manning's roughness coefficient and crop management factor (Table 1) can be assigned for each cell. Figure 7 shows the soil type distribution for the study area. Additionally, upon coupling the soil map with the cell map, the representative soil particle diameter was obtained for each cell (Soil Survey Division Staff 1993). The representative diameter of soil particles in river cells is based on field measurement of river bed materials (Water Resource Planning Institute 2001).

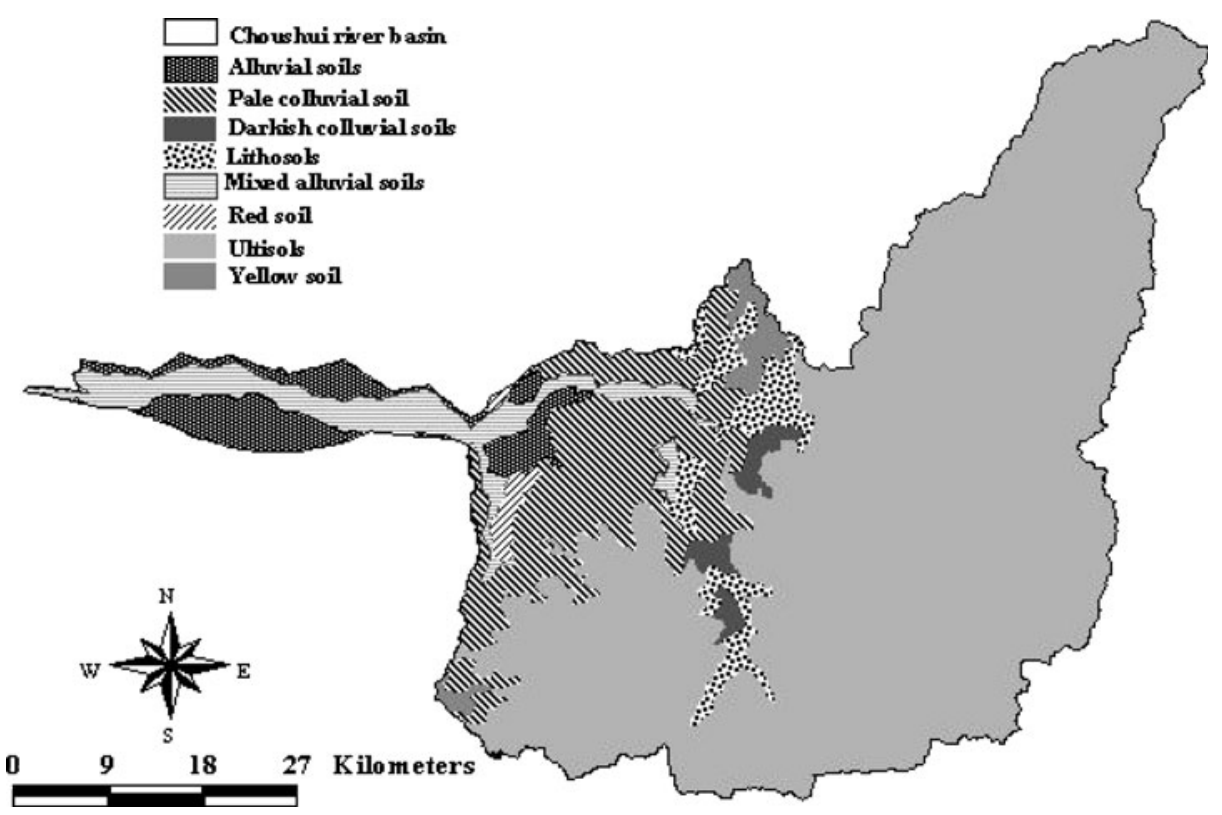

Fig. 7 Soil type distribution of the Chou-Shui River Basin 


\section{Calculation Procedures of GIS and PSED Model}

In summary, the procedures used to calculate water depth, suspended volumetric concentration, and sediment yield with the proposed PSED model, in conjunction with GIS, are as follows,

1. Use GIS to define subcatchments. Each subcatchment is further partitioned into multiple cells based on the appropriate resolution. These cells are characterized as land cells and river cells based on their properties.

2. Use GIS to analyze the hydrological and physiographical data including precipitation, vegetation, land uses, geometry, topology, elevation, weir coefficients, and particle diameters. Then save the results of the analysis in the database.

3. Prepare the input files for the PSED model using the database from step 2.

4. Calculate the overland flow using Eq. 8 to obtain the water elevation in each cell. $\Delta t=1$ second in all simulated rainfall events.

5. Simulate the soil erosion-deposition to obtain the volumetric concentration, bed variation, and bed elevation of each cell using Eqs. 19, 20, and 21, respectively.

6. Repeat step 4 using the bed elevation obtained from the step 5 until the end of the storm event.

\section{Simulation Conducted}

To verify the feasibility of this PSED when applied to a multi-watershed river basin to estimate flow discharge and sediment yield, two main case studies were considered. First, the simulations of flow discharge for three typhoon storm events, Typhoon Herb in 1996, Typhoon Zeb in 1998, and Typhoon Nari in 2001, were compared with the discharge measurements obtained from the river gauging stations in the Cho-Shui river basin to verify the accuracy of the discharge hydrographs simulated with the PSED. The suspended sediment concentration were also measured in river gauging stations, suspended sediment concentration multiplied by discharge is suspended sediment transport rate. Based on measured discharge and suspended sediment concentration, the relationship between flow discharge and sediment transport rate was obtained. Then, a total of 33 storm events in 1998 were simulated to compare the PSED calculated suspended sediment transport rate with the relationship between flow discharge and sediment transport rate generated with measured data at each river gauging station in the Cho-Shui river basin.

\section{Results and Discussion}

Since the available river gauging station discharge observations are more complete for typhoon storm events, the discharge hydrographs of three typhoon storm events which have relatively more intense rainfall and longer duration were simulated first. These simulated hydrographs were compared to the observed discharge hydrographs obtained from five river gauging stations in the Cho-Shui river basin (Figs. 8, 9 and 10). These five stations were: (1) Yu-Feng bridge station upstream of Cho-Shui river (located in the watershed of the Cho-Shui river mainstream); (2) Nei-Mao-Pu station (located in the watershed of the Chen-You-Lan river); (3) Tung-Tou station 

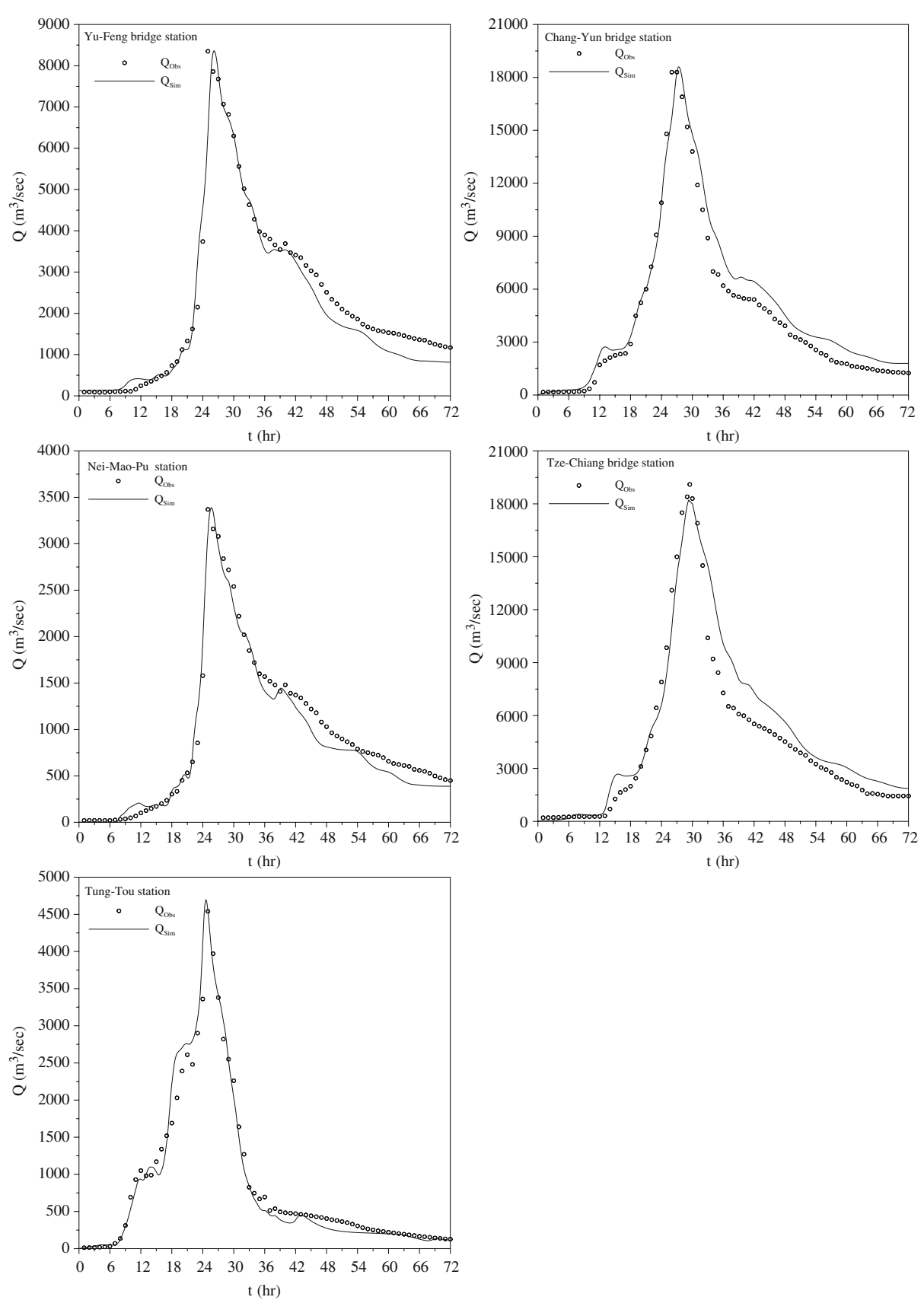

Fig. 8 The comparison between simulated and observed flow discharge at different river gauging stations for Typhoon Herb

(located in the watershed of the Chin-Shui river); (4) Chang-Yun bridge station downstream of the Cho-Shui river; and (5) Tzu-Chiang bridge station (located in the watershed of Cho-Shui river mainstream). 

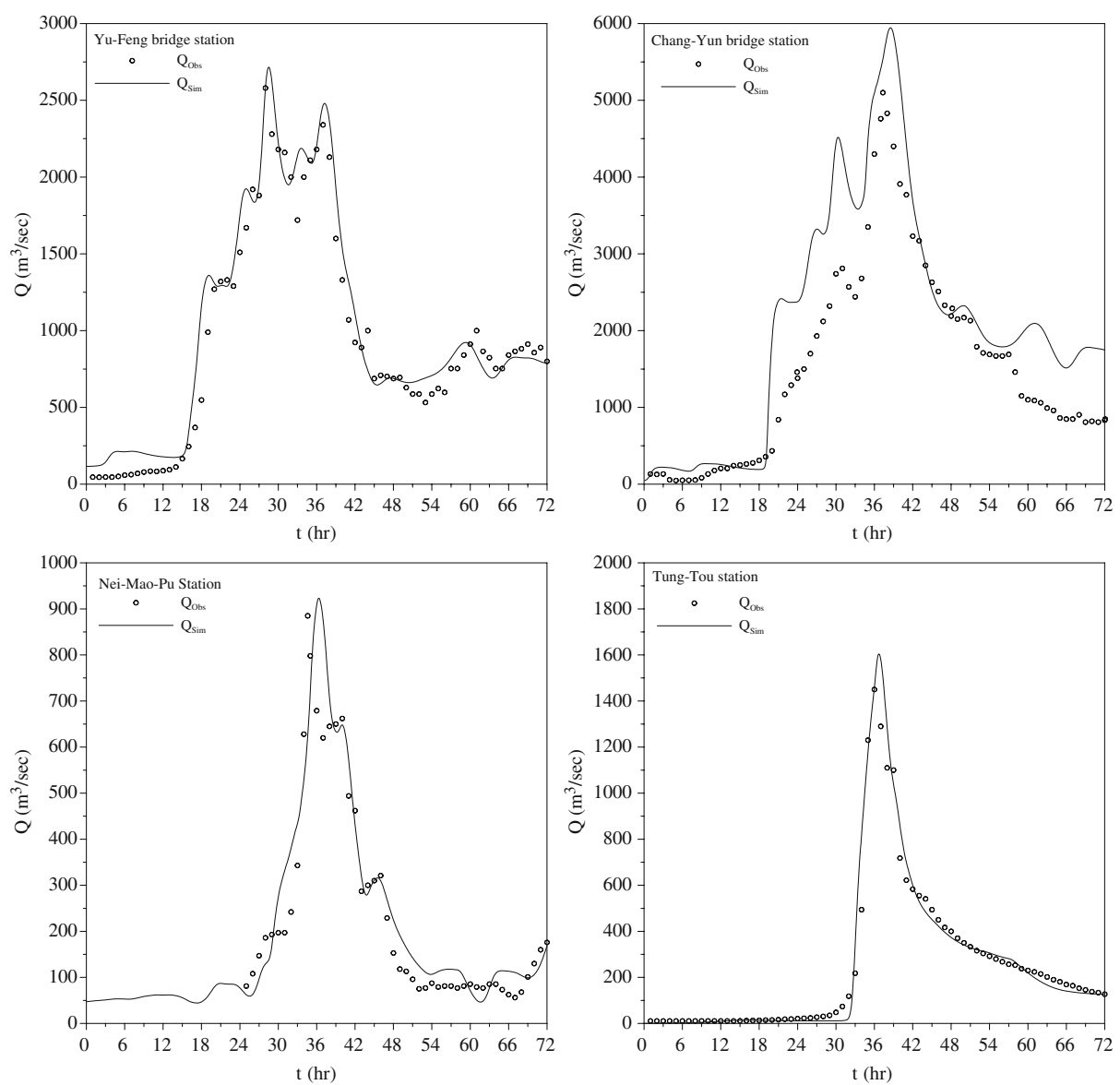

Fig. 9 The comparison between simulated and observed flow discharge at different river gauging stations for Typhoon Zeb (observed flow discharge data for Tzu-Chiang bridge station are not available)

Based on the observed discharge hydrographs, the spatially distributed rainfall and heterogeneous physiographic properties at different watersheds lead to significantly different discharge hydrographs for different river gauging stations, even for an identical typhoon storm event. For example, the shapes of the observed discharge hydrographs for Typhoon Herb at each station were single-peaked. However, for Typhoon Zeb, the observed discharge hydrograph at the Yu-Feng bridge station was multi-peaked, but at the Tung-Tou station the shape was single-peaked. Similar features can be seen for Typhoon Nari. At the Yu-Feng station, the shape of the hydrograph was single-peaked; however, hydrographs with double peaks were observed at the Chang-Yun bridge and Tung-Tou stations. This phenomenon implies that estimating flow discharge and sediment yield using simplified models (assuming homogeneous physiographic and hydrological parameters) in a multi-watershed river basin will not be reliable. The average relative root-mean-square errors of simulated discharge for river gauging stations with measured data are $10.13 \%, 16.74 \%$ and $8.28 \%$ in Typhoon Herb, Zeb and Nari, respectively. 

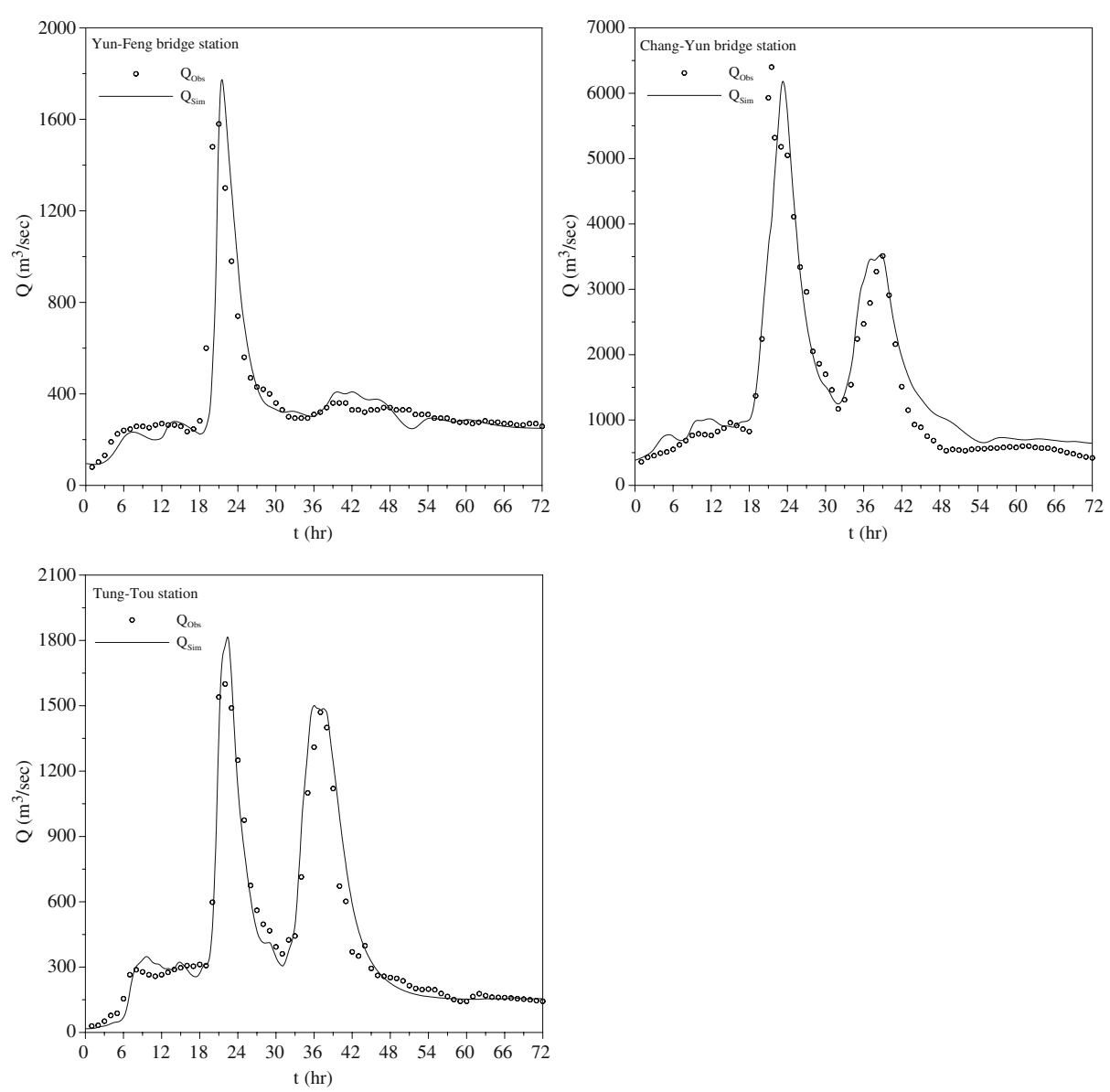

Fig. 10 The comparison between simulated and observed flow discharge at different river gauging stations for Typhoon Nari (observed flow discharge data for Nei-Mao-Pu and Tzu-Chiang bridge station are not available)

As shown, the shapes of simulated flow discharge hydrographs using the PSED model were in good agreement with observed discharge hydrographs at each station in different watersheds. The simulated timing and value of flood peaks were similar to the observed values, and the shapes of the simulated hydrographs agree with the observed data. This indicates that the PSED model is capable of describing the processes of runoff during rising and recession segments. According to the results shown thus far, the PSED model can be used to simulate reliable discharge hydrographs at each sub-watershed.

\section{Comparisons Between Simulated and Measured Suspended Sediment Transport Rates}

The PSED model can also be used to simulate suspended sediment concentration. In this study, data from Typhoon Herb were used to simulate suspended sediment 

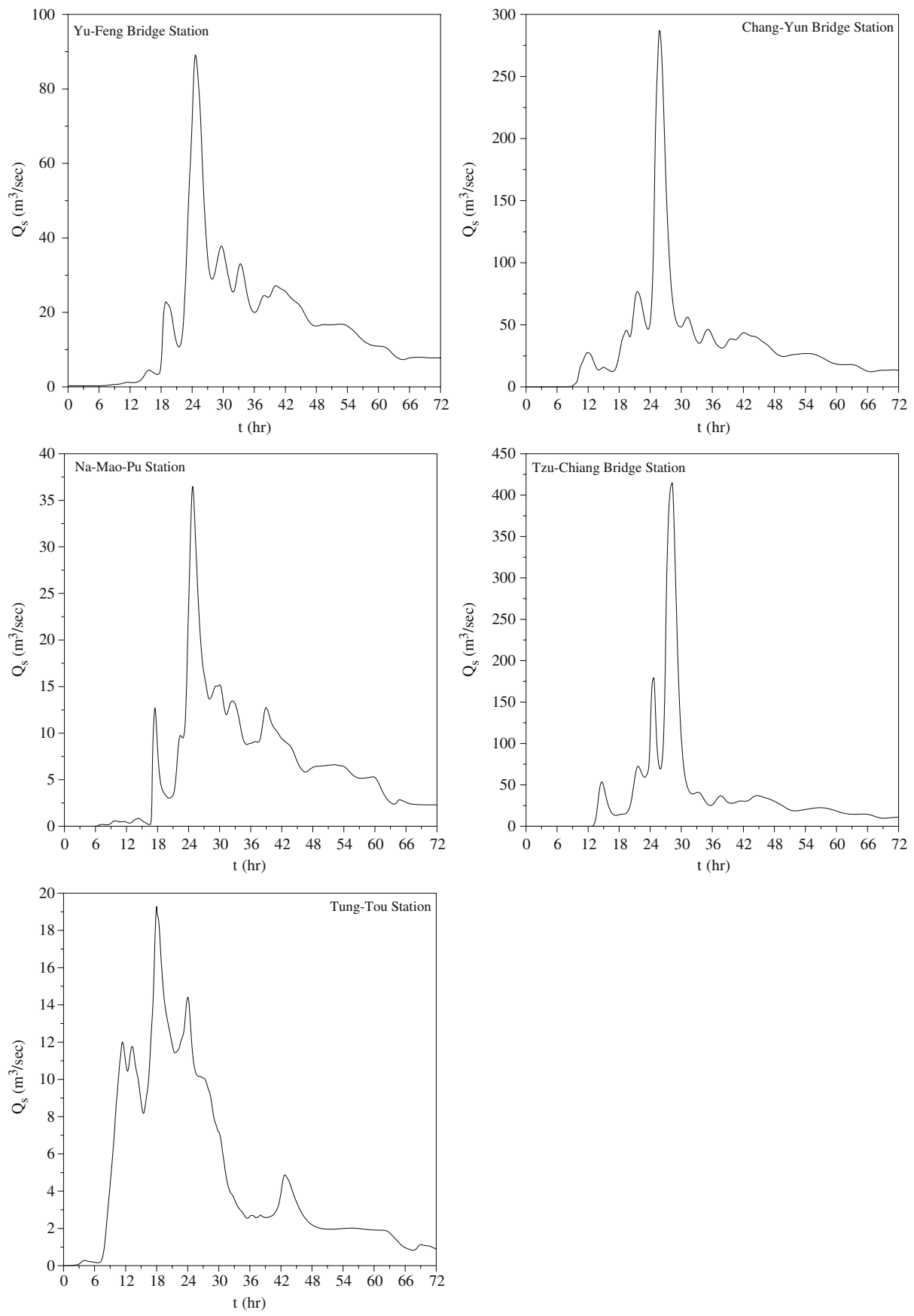

Fig. 11 The simulation of suspended sediment transport rate at each river gauging station for Typhoon Herb 
transport rates $\left(Q_{s}\right)$ at different stations (Fig. 11). Based on these results, the occurrence of intense rainfall would lead to not only greater flow discharge, but also higher sediment discharge. Moreover, the most significant sediment transport occurred while the flow discharge was the greatest.

In general, however, data of measured suspended sediment concentrations at river gauging stations are sparse, especially during Typhoon and storm events. There are generally no continuous suspended sediment concentration measurements during these events. Therefore, validating the simulated suspended sediment concentrations directly is difficult. In order to verify the simulated suspended sediment concentration hydrographs using the PSED in the Cho-Shui river basin, an alternative method was used in this study. This method used the relationship between observed flow at normal discharge levels and sediment transport rate obtained from each river gauging station to validate the simulated relationship at the same station. Although there are ten river gauging stations in the Cho-Shui river basin, extensive data of sediment transport rate measurements were only available for five stations (i.e. YuFeng bridge, Nei-Mao-Pu, Tung-Tou, Chang-Yun bridge, and Tzu-Chiang bridge stations). However, significant changes in the physiographic properties occurred in the Cho-Shui river basin after the violent Chi-Chi earthquake devastated Taiwan on September 21th, 1999. The impact of this earthquake led to increases in soil erosion and sediment yield and resulted in significant changes in the original relationship between flow discharge and sediment transport rate (Chen et al. 2003). Therefore only the data measured before September, 1999 were used in this study to generate observed relationship. As for simulations using the PSED, sediment transport rate

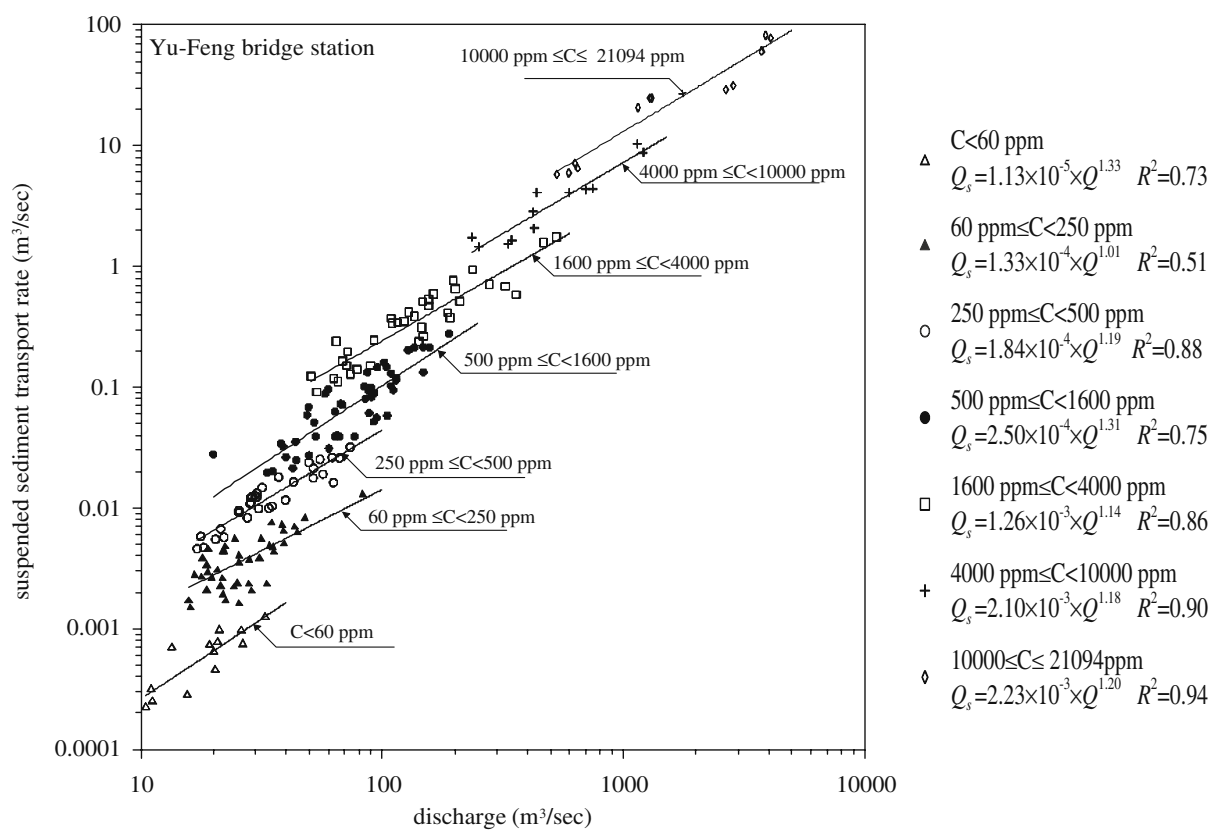

Fig. 12 Relationship between flow discharge and sediment transport rate for various suspended sediment concentrations at the Yu-Feng bridge station 
was simulated using data from 33 storm events occurring in 1998. The simulated results were then compared with field data at the five aforementioned river gauging stations.

Based on the relationship between observed flow discharge and sediment transport rate, a single flow discharge value could possibly correspond to different sediment transport rates. Generally, the relationship between observed flow discharge and sediment transport rate indicates that: (1) the distribution of sediment transport rates corresponding to large flow discharges is more concentrated; and (2) the variation of observed sediment transport rates with medium and small flow discharges are larger. Since for large flow discharge the variation of sediment transport rate is relatively small, the estimated errors would also be small compared to those with medium and small flow discharge rates. To avoid overestimating or underestimating sediment transport rates for medium and small flow discharges, a regression analysis was conducted, for various ranges of suspended sediment volumetric concentrations, to generate relationships between flow discharges and suspended sediment transport rates (Chen et al. 2006). This regression analysis was conducted for the five bridge stations (Figs. 12, 13, 14, 15 and 16).

Generally, the variance associated with sediment transport rate or sediment concentrations for smaller flow discharge is relative high, i.e. the distribution of observed data is scattered; however, the variance associated with sediment transport rate or sediment concentrations for large flow discharge is relative small, i.e. the distribution of observed data is more concentrated (American Society of Civil Engineers 1975). For example, the correlation coefficients of the regression equations are larger than 0.8 for high flow discharge but not for the equations with small flow discharge and low

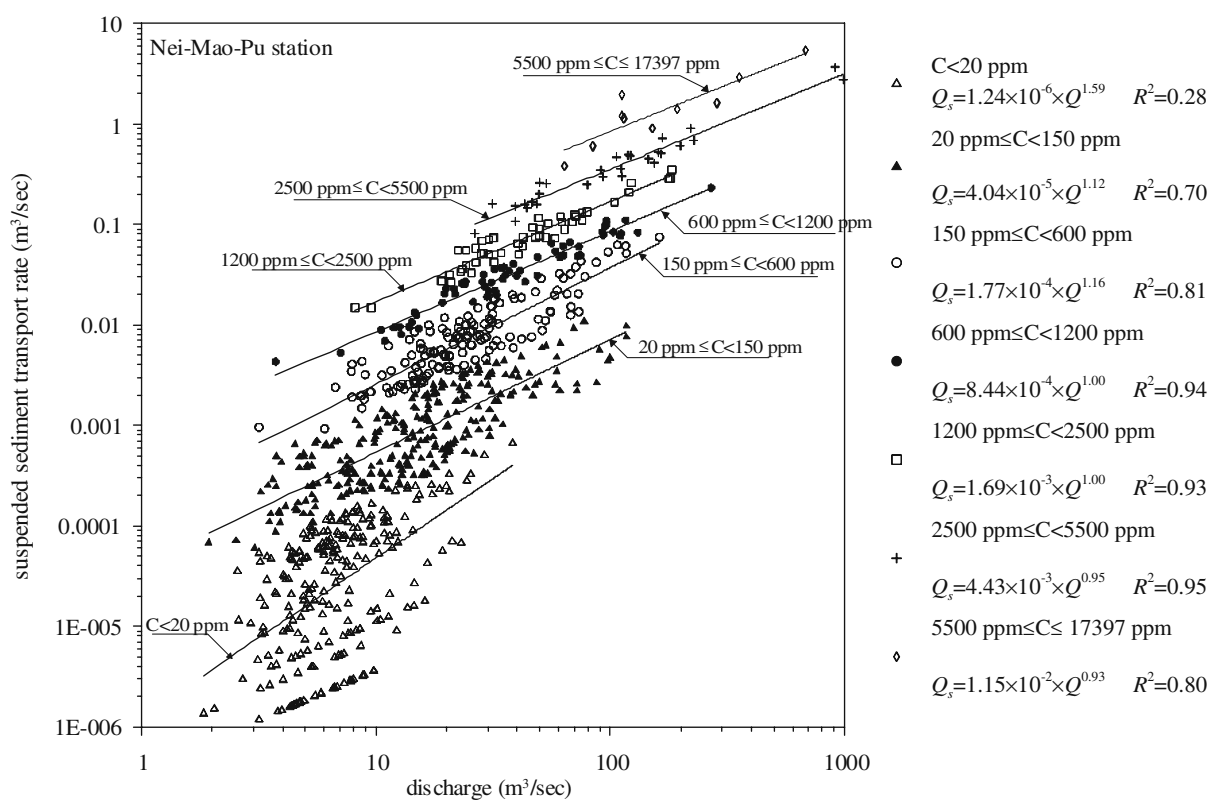

Fig. 13 Relationship between flow discharge and sediment transport rate for various suspended sediment concentrations at the Nei-Mao-Pu station 


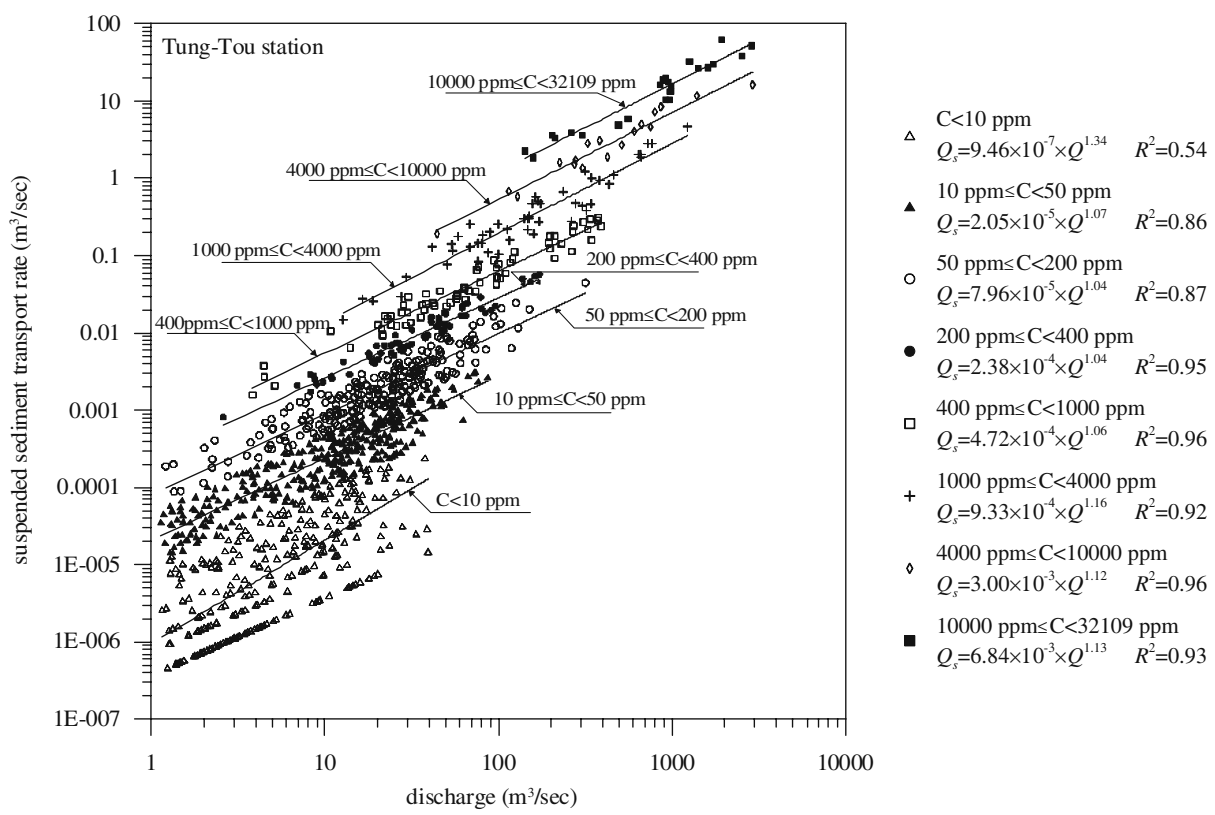

Fig. 14 Relationship between flow discharge and sediment transport rate for various suspended sediment concentrations at the Tung-Tou station

sediment concentration. These results indicate that regression equations are capable of describing the relationship between flow discharge and sediment transport rate.

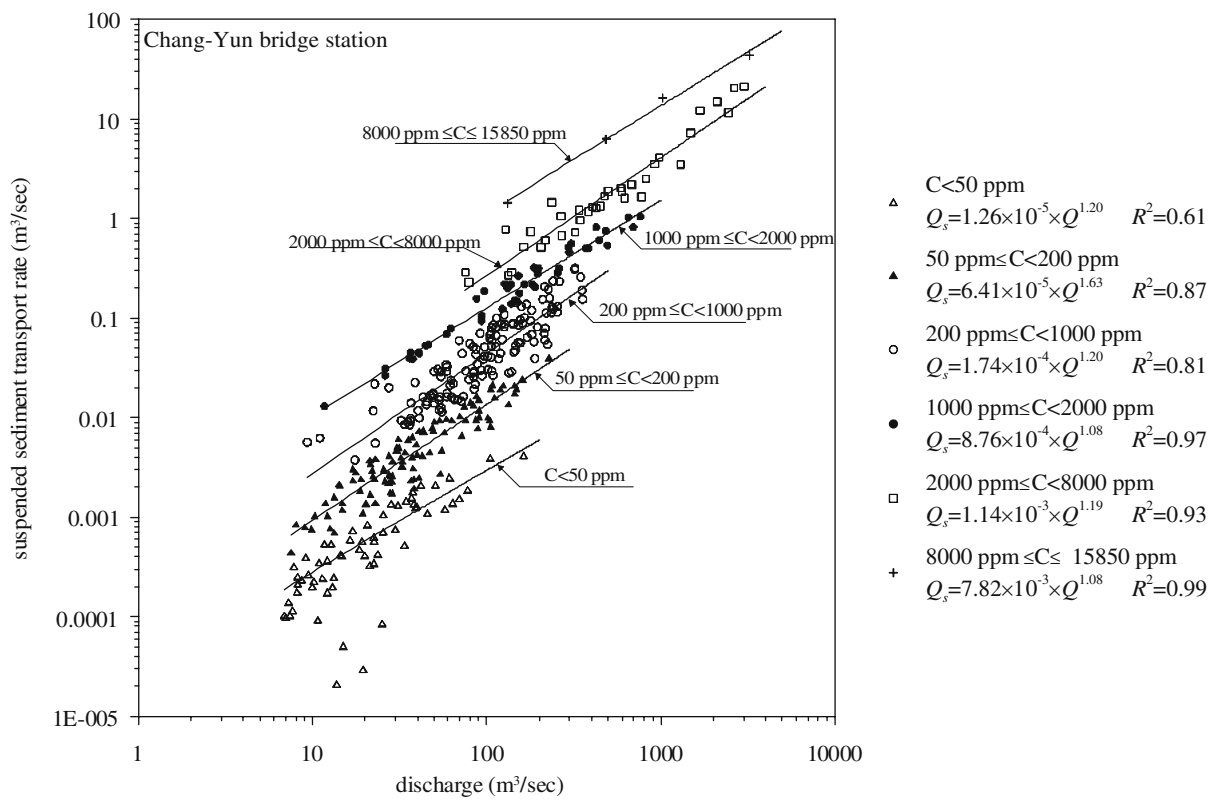

Fig. 15 Relationship between flow discharge and sediment transport rate for various suspended sediment concentrations at the Chang-Yun bridge station 


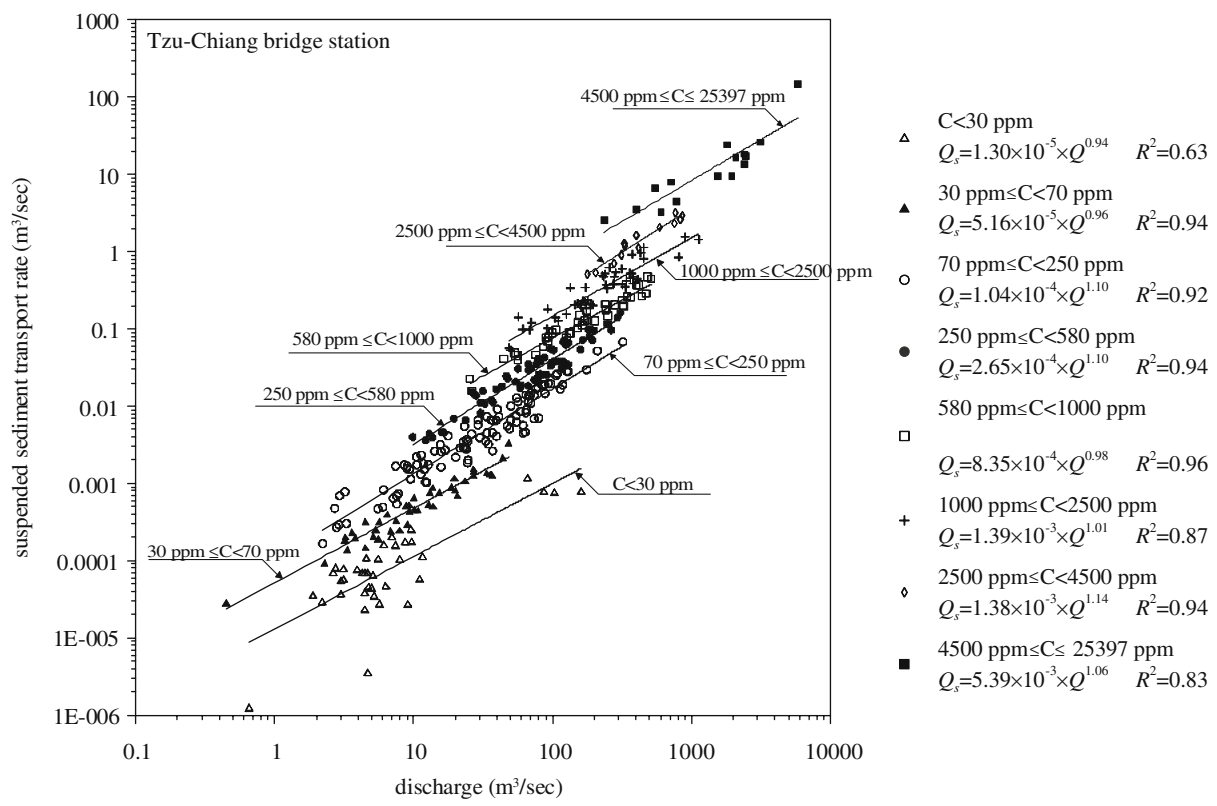

Fig. 16 Relationship between flow discharge and sediment transport rate for various suspended sediment concentrations at the Tzu-Chiang bridge station

The simulated relationships calculated with the PSED model using 33 storm events in 1998 are compared to the regression equations calculated from observed

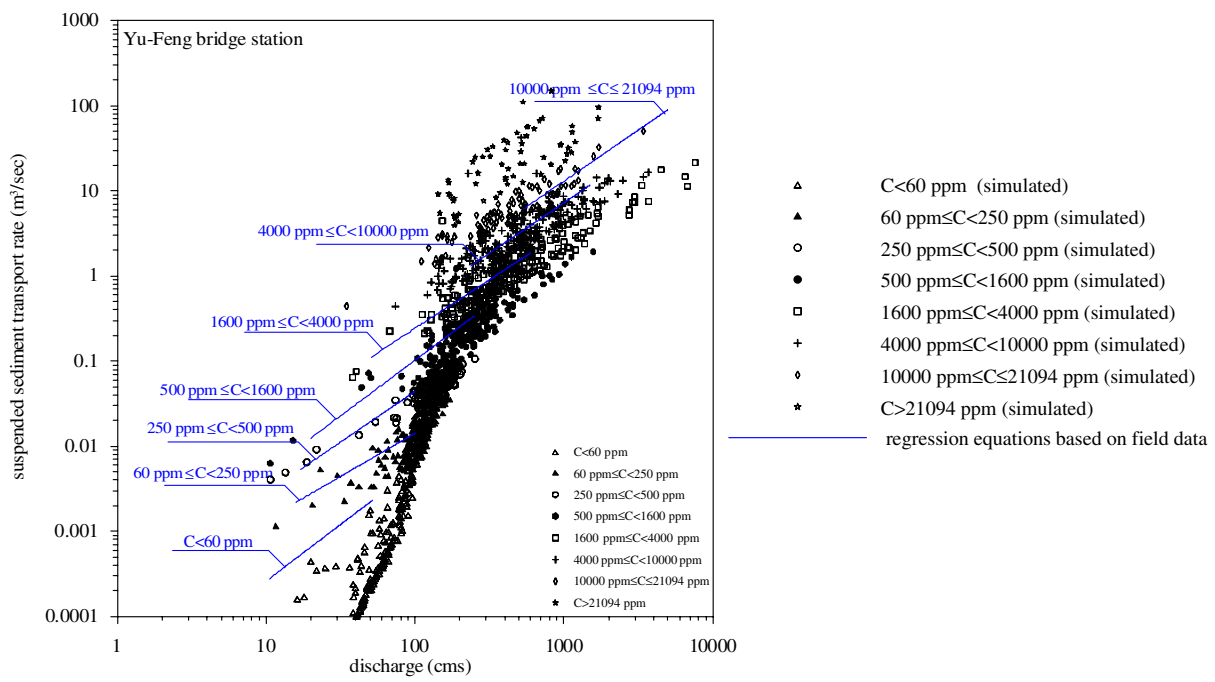

Fig. 17 Comparisons between simulated and observed flow discharge versus sediment transport rate relationships at the $\mathrm{Yu}$-Feng bridge station (star denotes the simulated concentrations larger than the greatest measured value) 


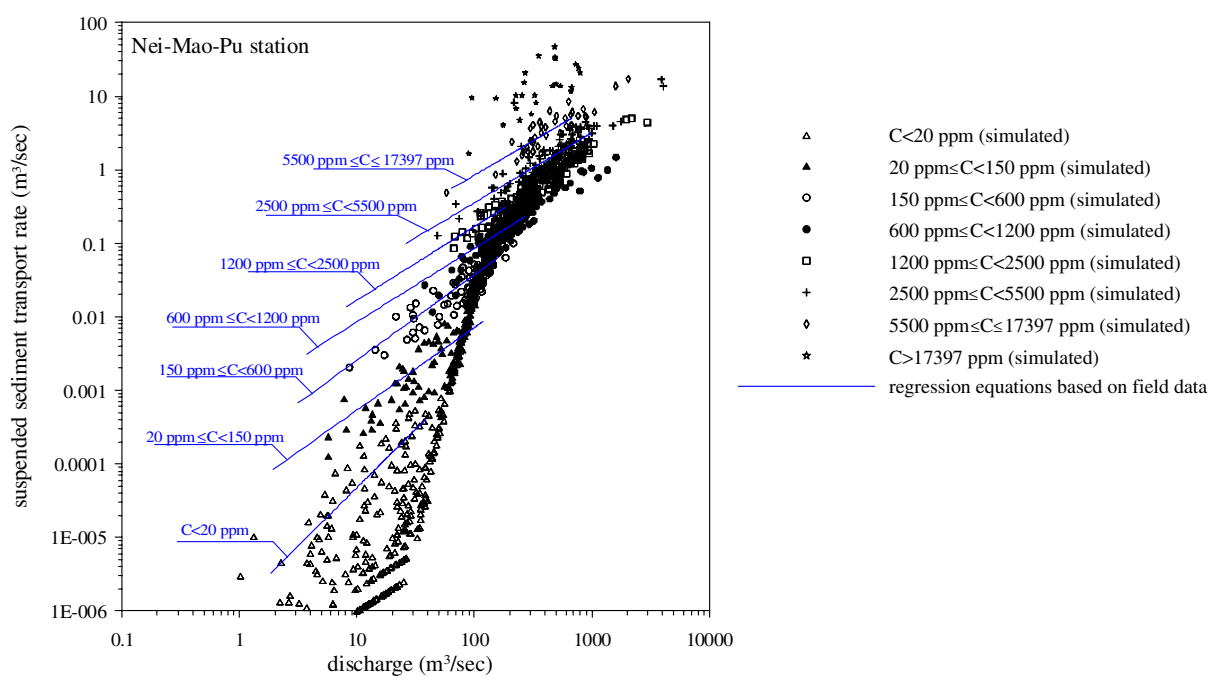

Fig. 18 Comparisons between simulated and observed flow discharge versus sediment transport rate relationships at the Nei-Mao-Pu station (star denotes the simulated concentrations larger than the greatest measured value)

field data (Figs. 17, 18, 19, 20 and 21). Due to the lack of measured data under severe conditions of high flow discharge and high sediment concentration, part of the simulation results fell outside the extended part of the regression equation where the simulated concentrations larger than the greatest measured value were denoted by a "star" in Figs. 17-21. Besides these outlying simulated values, the

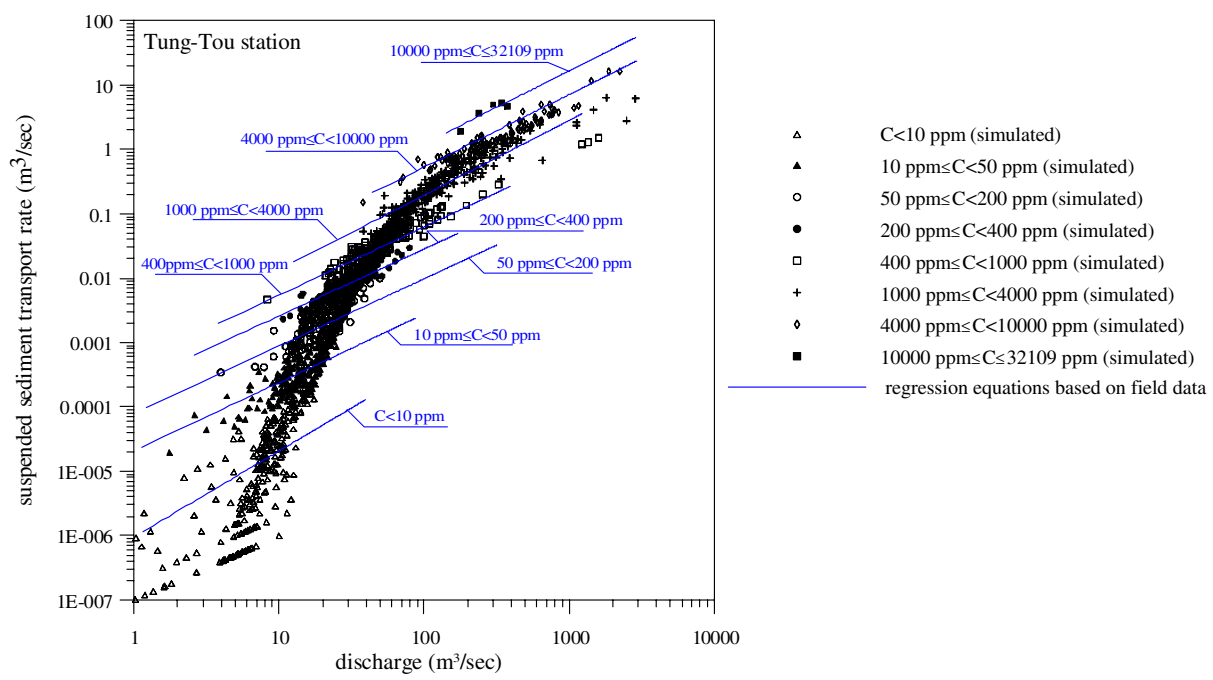

Fig. 19 Comparisons between simulated and observed flow discharge versus sediment transport rate relationships at the Tung-Tou station 


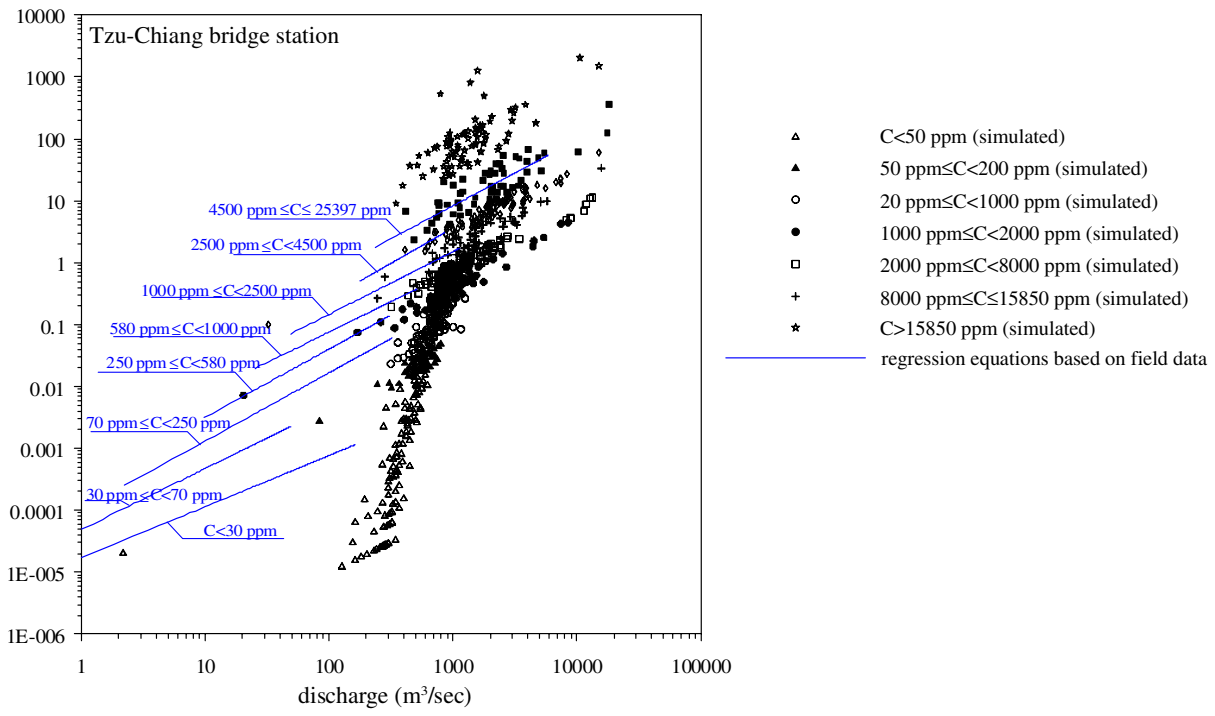

Fig. 20 Comparisons between simulated and observed flow discharge versus sediment transport rate relationships at the Chang-Yun bridge station (star denotes the simulated concentrations larger than the greatest measured value)

relationships between simulated flow discharge and sediment transport rate are in good agreement with the regression equations generated with observed data, especially when the flow discharges are relatively large. Since the results show

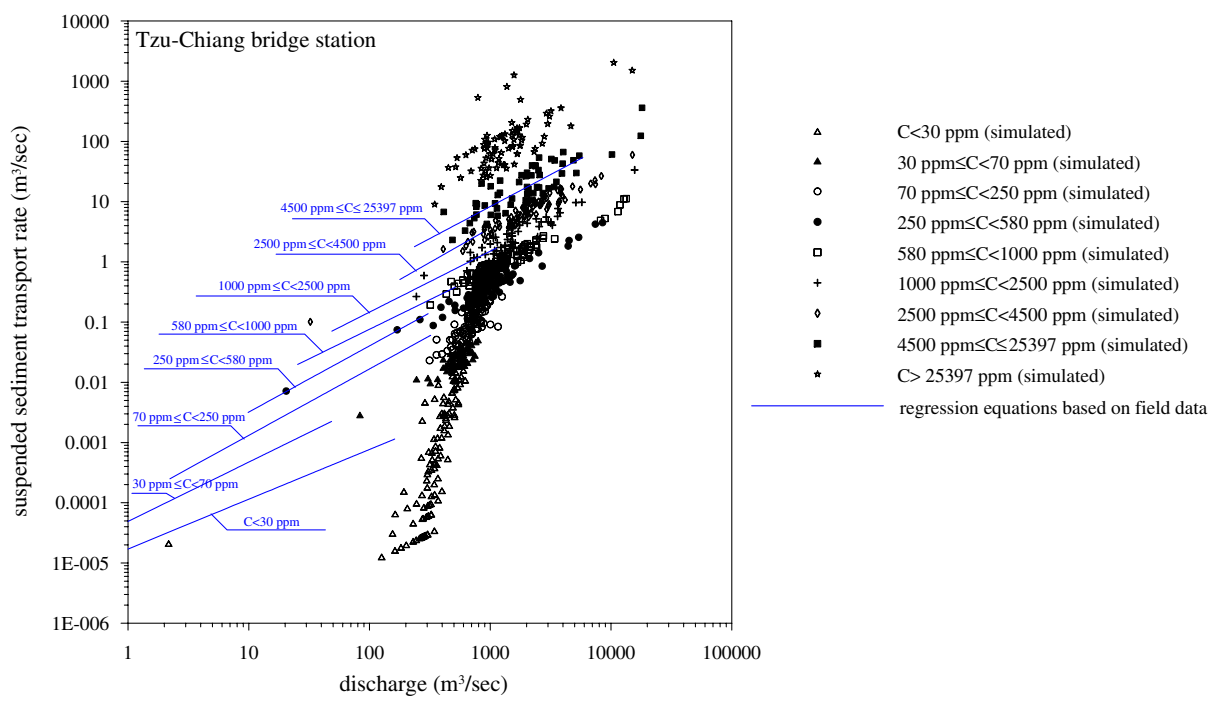

Fig. 21 Comparisons between simulated and observed flow discharge versus sediment transport rate relationships at the Tzu-Chiang bridge station (star denotes the simulated concentrations larger than the greatest measured value) 
that the simulated suspended sediment concentration is reasonable, the resulting calculation of suspended transport rate should also be reliable.

\section{Conclusion}

In this study, the coupling of a physiographic rainfall-runoff model, using GIS, and the physical processes of soil erosion and deposition in watershed is used to develop the PSED model for the calculation of flow discharge and suspended sediment transport rate at a multi-watershed river basin. Based on the simulations of three typhoon storm events, the shapes and the peak values of the simulated discharge hydrographs are similar to the measured flow discharges at each river gauging station, even though the shape of the runoff discharge hydrographs in each watershed may differ. A regression analysis was conducted between measured flow discharge and sediment transport rate to obtain the relationship between flow discharge and sediment transport rate at various ranges of suspended sediment concentrations. These relationships were then treated as benchmark and compared directly with the simulated results of the PSED model. The model simulations were conducted with the data from 33 storm events occurring in 1998. The distributions of simulated flow discharge versus suspended sediment transport rate are in good agreement with the regression equations generated with the measured data. These results indicate that the PSED model is able to simulate flow discharge and suspended transport rate for a multi-watershed river basin, and would be useful for the planning of hydraulic engineering and watershed management.

Open Access This article is distributed under the terms of the Creative Commons Attribution Noncommercial License which permits any noncommercial use, distribution, and reproduction in any medium, provided the original author(s) and source are credited.

\section{References}

American Society of Civil Engineers (1975) Sedimentation engineering, pp 472-476

Beasley DB, Huggins LF, Monke EJ (1980) ANSWERS: a model for watershed planning. Trans ASAE 23(4):938-944

Bhattarai R, Dutta D (2007) Estimation of soil erosion and sediment yield using GIS at catchment scale. Water Resour Manage 21:1635-1647

Brazier RE, Beven KJ, Freer J, Rowan JS (2000) Equifinality and uncertainty in physically-based soil erosion models: application of the GLUE methodology to WEPP, the water erosion prediction project for sites in the UK and USA. Earth Surf Process Landf 25:825-845

Chen CN, Tsai CH, Tsai CT (2003) The effect of Chi-Chi earthquake on soil erosion and sediment yield in Cho-Shui river basin. J Taiwan Water Conservancy 51(1):26-35

Chen CN, Tsai CH, Tsai CT (2004) A study of GIS linked the physiographic soil erosion-deposition model for watershed. J Chinese Inst Civil Hydraulic Eng 16(3):379-391

Chen CN, Tsai CH, Tsai CT (2006) Simulation of sediment yield from watershed by physiographic soil erosion-deposition model. J Hydrol 327:293-303

Chou WC (2010) Modelling watershed scale soil loss prediction and sediment yield estimation. Water Resour Manage 24:2075-2090

Chow VT, Maidment DR, Mays LW (1988) Applied hydrology. McGraw-Hill, United States, pp $153-155$

Hu SC, Lu JY, Wu IY, Chen TF (1995) Interrill erosion rates of high clay soils in Lien-Hua-Chi area. Taiwan Forestry Res 10(1):33-40 
Itakura T, Kishi T (1980) Open channel flow with suspended sediments. J Hydraul Div, ASCE 106(8):1325-1343

Jain MK, Das D (2010) Estimation of sediment yield and areas of soil erosion and deposition for watershed prioritization using GIS and remote sensing. Water Resour Manage 24:2091-2112

Jain MK, Kothyari UC, Raju KGR (2005) GIS based distributed model for soil erosion and rate of sediment outflow from catchments. J Hydraul Eng 131(9):755-769

Knisel WG (1980) CREAMS: a field scale model for chemicals, runoff and erosion from agricultural management systems. USDA Conservation Research Report 26

Ma MM (1995) The rainfall characteristics and erosivity in central and northern areas of Taiwan. Master thesis, Department of Civil Engineering, National Chung-Hsing University, Taichung

Mishra PK, Deng ZQ (2009) Sediment TMDL development for the Amite River. Water Resour Manage 23:839-852

Misra RK, Rose CW (1990) Annual for use of program GUEST, Division of Australian Environmental Studies Report. Griffith University, Brisbane

Morgan RPC, Quinton JN, Smith RE, Govers G, Poesen JWA, Chisci G, Torri D (1998) The EUROSEM model. In: Boardman J, Favis-Mortlock D (eds) Global change: modeling soil erosion by water. Springer, New York, pp 373-382

Murakami S, Hayashi S, Kameyama S, Watanabe M (2001) Fundamental study on sediment routing through forest and agricultural area in watershed. Annu J Hydraul Eng, JSCE 45:799-804 (in Japanese)

Mutchler CK, Young RA (1975) Soil detachment by raindrops. In: Proceedings of sediment-yield workshop, ARS-S-40, USDA

Nearing MA, Foster GR, Lane LJ, Finkner SC (1989) A process-based soil erosion model for USDAWater erosion prediction project technology. Trans ASAE 32(5):1587-1593

Paringit EC, Nadaoka K (2003) Sediment yield modelling for small agricultural catchments: landcover parameterization based on remote sensing data analysis. Hydrol Process 17:1845-1866

Renard KG, Foster GR, Weesies GA, Porter JP (1991) RUSLE, revised universal soil loss equation. J Soil Water Conserv 16(1):30-33

Rose CW, Williams JR, Sander GC, Barry DA (1983) A mathematical model of soil erosion and deposition process I: theory for a plane element. Soil Sci Soc Am J 47:991-995

Shimizu Y, Yamaguchi H, Itakura T (1990) Three-dimensional computation of flow and bed deformation. J Hydraul Eng 116(9):1090-1108

Soil Survey Division Staff (1993) Soil survey manual. Handbook No. 8, United States Department of Agriculture, pp 136-140

Sun H, Cornish PS, Daniell TM (2002) Contour-based digital elevation modeling of watershed erosion and sedimentation: erosion and sedimentation estimation tool (EROSET). Water Resour Res 38(11):1-10

Tseng TL, Chou FN (2000) Numerical algorithm of Thiessen polygons method. J Taiwan Water Conservancy 48(3):43-51

Tsai CT, Tsai CH (1997) A study on the applicability of discharge formulas for trapezoidal broadcrested weirs. J Taiwan Water Conservancy 45(2):29-45

Wang G, Hapuarachchi P, Ishidaira H, Kiem AS, Takeuchi K (2009) Estimation of soil erosion and sediment yield during individual rainstorms at catchment scale. Water Resour Manage 23:14471465

Water Resource Planning Institute (2001) A survey of Chou-Shui River basin for integral administration. Technical Report, Water Resource Agency (MOEA)

Williams JR, Jones CA, Dyke PT (1984) A modeling approach determining the relationship between erosion and soil productivity. Trans ASAE 27:129-144

Wischmeier WH, Smith DD, Uhland RE (1958) Evaluation of factors in the soil loss equation. Agric Eng 39:458-462

Wongsa S, Nakui T, Iwai M, Shimizu Y (2002) Runoff and sediment transport modeling for mountain river. In: River flow 2002-international conference on fluvial hydraulic. Belgium, pp 683-691

Young RA, Onstad CA, Bosch DD, Andersen WP (1989) AGNPS: a nonpoint-source pollution model for evaluating agricultural watersheds. J Soil Water Conserv 44:168-173

Yuan ZJ, Cai QG, Chu YM (2007) A GIS-based distributed soil erosion model: a case study of typical watershed, Sichuan basin. Inter J Sediment 22(2):120-130 